\title{
Bank specific and macroeconomic determinants of bank profitability: empirical evidence from the China banking sector
}

\begin{abstract}
This paper seeks to examine the determinants of the profitability of the Chinese banking sector during the post-reform period of 2000-2005. The empirical findings from this study suggest that all the determinants variables have statistically significant impact on China banks profitability. However, the impacts are not uniform across bank types. We find that liquidity, credit risk, and capitalization have positive impacts on the state owned commercial banks (SOCBs) profitability, while the impact of cost is negative. Similar to their SOCB counterparts, we find that joint stock commercial banks (JSCB) with higher credit risk tend to be more profitable, while higher cost results in a lower JSCB profitability levels. During the period under study, the empirical findings suggest that size and cost results in a lower city commercial banks (CITY) profitability, while the more diversified and relatively better capitalized CITY tend to exhibit higher profitability levels. The impact of economic growth is positive, while growth in money supply is negatively related to the SOCB and CITY profitability levels.
\end{abstract}

Keyword: Bank profitability; Multivariate regression analysis; China 